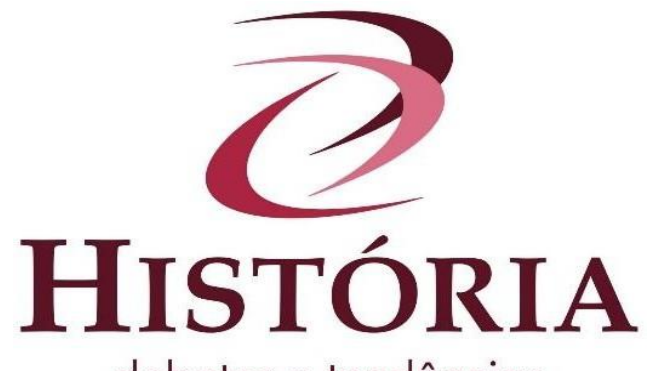

\title{
A União Central dos Poloneses do Brasil e a imposição cultural nacional $(1930-1938)^{i}$
}

\section{The Central Union of Poles in Brazil and the national cultural imposition (1930 - 1938)}

\section{Centralny Związek Polaków w Brazylii a narzucanie kultury narodowej (1930-1938)}

Resumo: Este trabalho tem como objetivo analisar a União Central dos Poloneses do Brasil, na sua perspectiva de promoção da cultura étnica, como forma de manutenção da nacionalidade polonesa nos núcleos étnicos e o fechamento compulsório por meio da nacionalização, como forma de imposição cultural promovida pelas instâncias políticas ideológicas do Estado Novo no Brasil. A organização de instituições étnicas fora importante para a propagação e manutenção de uma cultura trazida com os imigrantes, porém, transformada e atualizada nos espaços culturais de inserção, com inferências decisivas tanto das instâncias governamentais polonesas, na promoção da cultura étnica entre os imigrantes que aqui estavam, quanto, dos processos nacionalizadores brasileiro na Era Vargas. Para a escrita deste artigo foram analisadas documentações consulares do MSZ polonês do ano de 1938, bem como artigos de periódicos étnicos que circulavam nos núcleos de imigração polonesa do Brasil. No entanto, a investigação histórica de instituições étnicas demanda alguns cuidados na apropriação de sentidos e organizações das informações possíveis das fontes de pesquisa. A história de instituições ou rede mais amplas de sociabilidade não se pautam pelas simples análises de documentos, sejam eles oficiais ou de quaisquer outras fontes. Pode-se questionar, sobretudo, se os conhecimentos históricos podem fornecer verdades. Para Reis (2000, p 325), há diversas contestações que relativizam as verdades históricas: o conhecimento está ligado à época de produção e à subjetividade do autor; verdades inverificáveis pela experiência e fontes produzidas e manipuladas conforme as expectativas direcionadas. Para Foucault (2000, p. 14), a própria ideologia é a verdade representada numa perspectiva de relação de poder, nos chamados regimes de verdades ${ }^{1}$ e em suas representações.

Palavras-chave: Poloneses. Redes de Sociabilidade. Nacionalização.

\begin{abstract}
This article aims to analyze the Central Union of Poles in Brazil, in his perspective of promoting ethnic culture, as a way of maintaining Polish nationality in ethnic groups and the compulsory closure through nationalization, as a form of promoted cultural imposition by the ideological political instances of the Estado Novo in Brazil. The organization of ethnic institutions had been important for the propagation and maintenance of a culture brought with immigrants, however, transformed and updated in the cultural
\end{abstract}


spaces of insertion, with decisive inferences both from the Polish governmental bodies, in the promotion of ethnic culture among the immigrants who here were, how much, of the Brazilian nationalizing processes in the Era Vargas. To write this article, consular documentation of the Polish MSZ from 1938 was analyzed, as well as articles from ethnic journals circulating in Polish immigration centers in Brazil. However, the historical investigation of ethnic institutions demands some care in the appropriation of meanings and organizations of the possible information from the research sources. The history of broader sociability institutions or networks is not based on simple analysis of documents, whether official or from any other sources. One may question, above all, whether historical knowledge can provide truths. For Reis (2000, p 325), there are several challenges that put historical truths in perspective: knowledge is linked to the time of production and the author's subjectivity; truths unverifiable by experience and sources produced and manipulated according to the directed expectations. For Foucault (2000, p. 14 ), ideology itself is the truth represented in a power relationship perspective, in the socalled regimes of truths and in their representations.

Keywords: Polish. Sociability Networks. Nationalization.

Streszczenie: Praca ma na celu analizę Centralnego Związku Polaków w Brazylii w perspektywie promowania kultury etnicznej, jako sposobu na utrzymanie narodowości polskiej w grupach etnicznych oraz przymusowego zamknięcia przez nacjonalizację, jako formy promowanej narzucenia kulturowego ideologicznej instancji politycznej Estado Novo w Brazylii. Organizacja instytucji (organizacji) etnicznych była ważną dla krzewienia i utrzymania kultury przywiezionej przez imigrantów, jednak przekształcona i zaktualizowana $\mathrm{w}$ kulturowych przestrzeniach insercji, $\mathrm{z}$ decydującymi wnioskami zarówno ze strony polskich organów rządowych, jak i dla promocji kultury etnicznej wśród imigrantów, którzy tutaj się osiedlili i byli poddawani brazylijskim procesom nacjonalizacyjnym $\mathrm{w}$ erze Vargas. Aby napisać ten artykuł, przeanalizowano dokumentację konsularną polskiego MSZ z 1938 r., a także artykuły z czasopism etnicznych krążących w polskich ośrodkach imigracyjnych w Brazylii. Jednak historyczne badanie instytucji etnicznych wymaga pewnej staranności w przyswajaniu znaczeń i organizacji możliwych informacji ze źródeł badawczych. Historia szerszych instytucji czy organizacji towarzyskich nie opiera się na prostej analizie dokumentów, czy to oficjalnych, czy z jakichkolwiek innych źródeł. Przede wszystkim można kwestionować, czy wiedza historyczna może dostarczyć prawd. Dla Reis (2000, s. 325) istnieje kilka wyzwań, które stawiają prawdy historyczne w perspektywie: wiedza jest związana $\mathrm{z}$ czasem produkcji i podmiotowością autora; prawdy nieweryfikowalne przez doświadczenie i źródła produkowane i manipulowane zgodnie $\mathrm{z}$ ukierunkowanymi oczekiwaniami. Dla Foucault (2000, s. 14) sama ideologia jest prawdą reprezentowaną w perspektywie relacji władzy, w tzw. reżimach prawd oraz w ich przedstawieniach.

Slowa kluczowe: Polacy. Organizacje towarzyskie. Nacjonalizacja.

\section{Considerações iniciais}

Os primeiros esforços de condução da etnicidade polonesa no Brasil, resultaram da formação dos primeiros espaços de convívio, como as primeiras capelas e sociedades que foram sendo organizadas espontaneamente, sob a égide de lideranças étnicas que atuavam 
nos diferentes núcleos de imigração. Diferentes foram os esforços posteriores pela organização dessas sociedades em instituições mais amplas, por meio da mobilização de intelectuais do território étnico polonês, da antiga Galícia austríaca e depois pelas instâncias religiosas e oficiais mais representativas, como fora o clero da Igreja Católica e os agentes culturais ou instrutores de ensino enviados pelo Ministério das Relações Exteriores polonês. Estas instituições étnicas isoladas eram mobilizadas social e culturalmente em redes com o objetivo de agregar indivíduos e sociedades dispersas pelos agrestes e rincões brasileiros, com suas perspectivas finalidades existenciais. A mais representativa dessas associações, talvez tenha sido a União Central dos Poloneses do Brasil, ou simplesmente CZP, sigla em polonês para Centralny Zwiąek Polaków. Esta instituição representou os esforços mais significativos, como se fosse possível, da tentativa de homogeneização étnica da imigração polonesa no Brasil.

A organização de instituições étnicas fora importante para a propagação e manutenção de uma cultura trazida com os imigrantes, porém, transformada e atualizada nos espaços culturais de inserção, com inferências decisivas tanto das instâncias governamentais polonesas, na promoção da cultura étnica entre os imigrantes que aqui estavam, quanto dos processos nacionalizadores brasileiros na Era Vargas. Este trabalho tem como objetivo analisar a União Central dos Poloneses do Brasil, na sua perspectiva de promoção da escolarização, como forma de manutenção da nacionalidade polonesa nos núcleos étnicos e, a sua nacionalização compulsória como forma de imposição cultural promovida pelas instâncias políticas ideológicas do Estado Novo no Brasil. No entanto, a investigação histórica de instituições étnicas demanda alguns cuidados na apropriação de sentidos e organizações das informações possíveis das fontes de pesquisa.

Um pressuposto teórico que compreendo como importante ou relevante a ser considerado, sobre a investigação histórica dos processos culturais dos imigrantes poloneses, é que a verdade é uma invenção. Compreendo que possuímos representações da realidade. A história de instituições ou rede mais amplas de sociabilidade não se pautam pelas simples análises de documentos, sejam eles oficiais ou de quaisquer outras fontes. Pode-se questionar, sobretudo, se os conhecimentos históricos podem fornecer verdades. Para Reis (2000, p 325), há diversas contestações que relativizam as verdades históricas: o conhecimento está ligado à época de produção e à subjetividade do autor; verdades inverificáveis pela experiência e fontes produzidas e manipuladas conforme as expectativas direcionadas. Para Foucault (2000, p. 14), a própria ideologia é a verdade representada numa perspectiva de relação de poder, nos chamados regimes de verdades e 
em suas representações. As representações são o campo em que as ciências humanas encontram sua significação de existência confrontando-se com a emergência dos discursos que as constituem. O conhecimento está para um determinado contexto e tempo. O que dá credibilidade histórica a uma narrativa é a estrutura coerente do método de pesquisa e a subjetividade reflexiva crítica em perguntar pelo processo de produção das fontes. Tomar para si uma decisão sobre como elaborar suas narrativas com o máximo de cuidado com as fontes, num processo epistemológico crítico. Na adequação teórica e metodológica com o objeto, existe uma dimensão de preservação de símbolos e mitos subsistentes ao tempo e ajudando na construção das representações da realidade e, por consequência, das identidades dos grupos sociais e sua otimização em narrativas. Essa perspectiva metodológica de pensar a história por meio do simbólico aponta novos caminhos para construir as narrativas históricas. Mesmo a cultura étnica é uma forma de condução e produção dos processos identitários que conduz os indivíduos na preservação de simbologias, valores e conhecimentos que atuam nas transformações dos espaços sociais.

As representações subjetivas simbólicas possibilitam a organização da pesquisa e suas fontes. As afirmações e verdades representadas possuem uma interação direta com os significados num contexto ${ }^{i i i}$ determinado. Desse modo, por exemplo, a construção de sentido, efetuada na leitura ou na escuta das fontes, varia de acordo com os tempos, os lugares e os métodos de pesquisa. Tudo o que se diz e se afirma é posto, afirmado, por meio de um contexto subjetivo e sociocultural condicionador das formas de dizer. "As significações múltiplas e móveis de um texto dependem das formas por meio das quais é recebido por seus leitores ou ouvintes". (CHARTIER, 1991, p.178). As representações simbólicas estão nas constituições das fontes e, por consequência, a interpretação leva em conta que o que está construído participa integralmente desse processo. Dessa forma, tal entendimento passa a revelar um processo de constituição de fontes e de repensar a aproximação do objeto pesquisado com uma rede de interações interdisciplinares. O real passa a ser construído por meio do simbólico e da representação existentes no mundo e em seus fenômenos.

Concordo com Barth (1976) que a cultura é gerada por um olhar dinâmico em bases empíricas na construção de eventos por parte dos agentes sociais num processo criativo resultado da luta dos atores sociais em superar as imposições resistentes do mundo. A cultura é capaz de reunir processos idênticos, produtores de consensos, envolvendo o sistema de significação do mundo e do real, regulando condutas e organizando a vida social. A pesquisa histórica como um processo de construção de 
sentidos, permite formar ou construir símbolos e códigos de significação, por meio das representações formadoras de consensos sobre fenômenos e objetos. Ou seja, um processo interativo de organizar verdades objetos e sentidos.

\section{Redes de sociabilidade mais amplas}

As primeiras sociedades e associações estavam dentre esses espaços formalizados de convívio, que influenciaram o destino e a formatação do conteúdo étnico com ingerências nos rumos da etnicidade e formação dos espaços culturais. Em boa parte dos núcleos da imigração polonesa do Brasil as primeiras sociedades são formadas em diferentes municípios, tendo como prerrogativa a organização da escolarização. ${ }^{\text {iv }}$ No término da Primeira Guerra Mundial, com a reconstrução da Polônia, a organização social dos imigrantes poloneses estava difundida em sociedades que organizavam a vida cultural da imigração. Diferentes fontes, que registram a organização social dos imigrantes poloneses, como livros de atas e protocolos anteriores a $1918,{ }^{\mathrm{v}}$ confirmam que havia uma importante rede de socialização entre este grupo étnico, representada pelas sociedades e associações.

Desde a vinda dos primeiros grupos de imigrantes poloneses para o Brasil, diferentes sociedades organizavam suas escolas com a finalidade de promover ensino elementar nos núcleos de concentração de famílias desses imigrantes. Esse processo inicia-se com a organização de espaços improvisados, na casa de pessoas mais instruídas ou mesmo em algumas capelas, que eram utilizadas como espaço de ensino. Conforme anotações gerais do Cônsul polonês Kazimierz Głuchowski no Brasil, em publicação de 1927, eram raros ou inexistentes os lugares que não possuíam uma sociedade com finalidades escolares. Essas sociedades estavam filiadas a duas organizações centrais principais, fundadas posteriormente à Primeira Guerra Mundial em Curitiba: a Kultura e a Oświata. ${ }^{\mathrm{vi}}$

A associação Kultura de cunho progressista teve sua fundação no dia 28 de março de 1921, reunindo sociedades com o nome oficializado de União das Sociedades Polonesas Kultura. Dentre seus objetivos estavam agregar escolas e sociedades numa organização mais ampla; melhorar o processo de ensino étnico; organizar bibliotecas, organizar a formação de professores, bem como promover o aperfeiçoamento da organização das centenas de sociedade que estavam em funcionamento no Brasil. ${ }^{\text {vii }}$ Dentre 
as atividades relevantes desempenhadas pela associação, em relação ao ensino das comunidades étnicas polonesas, estavam a organização de escolas, cursos de formação de professores e a produção e publicação de livros didáticos. Além do desenvolvimento dessas ações, a Kultura buscava estabelecer estreitamento das relações com o governo polonês que enviou professores profissionais para orientar o funcionamento desta associação. ${ }^{\text {viii }}$ A ação da Kultura foi importante para elevar o nível de ensino escolar étnico de modo geral nas localidades com maiores contingentes étnicos deste grupo de imigrantes.

Porém, devido a Kultura possuir um entendimento do sentido da polonidade mais ligado ao ativismo social e por se tratar de uma associação leiga de cunho progressista, em que os preceitos religiosos não eram considerados tão importantes, na condução das atividades organizacionais étnicas, não demoraram para surgir atritos e disputas diretamente com o clero, que compreendia que a religiosidade era uma instância fundante para a mobilização e organização da vida nas comunidades polonesas. Segundo este entendimento, as sociedades deveriam estar atreladas ao espírito do catolicismo. Em contraposição a Kultura, fundou-se no dia 11 de dezembro de 1921 a Associação das Sociedades e Escolas Católicas Polonesas Oświata. Conforme seus estatutos registrados no ano de $1923{ }^{\text {ix }}$ a finalidade da Oświata era a difusão do ensino e promover ações em relação ao desenvolvimento material e espiritual dos associados. Dentre os principais objetivos da Associação Oświata, também estavam a formação de professores, a produção e publicação de livros didáticos, bem como a organização de bibliotecas e círculos de leitura. A Oświata disponibilizava para os sócios em uma biblioteca central 3.217 obras, com livros de literatura, organização pedagógica e livros didáticos curriculares para as escolas étnicas. ${ }^{\mathrm{x}}$ Os cursos de formação geralmente eram realizados nos períodos de férias e envolviam não só escolas e professores filiados à Oświata. Conforme Gardolinski (1977), desses cursos também participavam professores filiados à Kultura.

As atividades da Kultura e da Oświata se somaram ao processo organizativo das escolas, na mobilização étnica em torno da disputa pela imposição do discurso do entendimento de polonidade. Da união da Kultura e da Oświata em 1930 foi possível a organização da Central dos Poloneses do Brasil. A Oświata, após desentendimentos com a organização do CZP, retoma suas atividades de forma autônoma. Após a Campanha de nacionalização, a associação mudou o nome para Federação Católica e funcionou até 18 de julho de 1943, quando encerrou suas atividades. ${ }^{\text {xi }}$ As redes amplas de sociabilidade dos 
imigrantes poloneses no Brasil, desenvolveram um importante trabalho de manutenção de diferentes tipos de polonidade.

\section{CZP - A União Central dos Poloneses do Brasil}

As tentativas de mobilizar as ações étnicas centralizadas numa mesma instituição era um desejo ainda do início da organização das sociedades e comunidades dos imigrantes poloneses no Brasil, conforme atesta Głuchowski (2005). Porém, as desavenças entre orientações ou ideários distintos, acabavam melindrando quaisquer iniciativas para a formação de uma organização mais ampla. Para Wachowicz (1981), graças à interferência do consulado polonês, que buscou amenizar as divergências entre Kultura e Oświata, maiores associações que organizavam a vida cultural étnica dos imigrantes poloneses na época, foi criada em 1930 a União Central dos Poloneses no Brasil ou simplesmente CZP. ${ }^{\text {xii }}$ A necessidade de construção da União Central dos Poloneses no Brasil saiu fortalecida, após lideranças étnicas polonesas brasileiras participarem do Primeiro Congresso dos Poloneses do Exterior em Varsóvia, em 1929. A partir desse congresso a ideia de centralizar esforços na resolução de questões específicas começou a assumir formas reais. Uma das principais necessidades apresentadas pela delegação brasileira, que participou do congresso, era que em períodos anteriores, em que muitos poloneses chegaram ao Brasil, não havia o devido acompanhamento dos países que dominavam os territórios étnicos, bem como, uma instituição ampla que pudesse assumir a organização dos imigrantes em terras brasileiras.

De acordo com o bissemanário Lud, o chamado primeiro Congresso da União Central dos Poloneses no Brasil, ocorreu nos dias 22 e 23 de março de 1930, ${ }^{\text {xiii }}$ marcando a organização dos estatutos e a fundação da CZP. Władysław Neumann, editor do bissemanário, dizia que alguns que presenciaram os insucessos das tentativas anteriores de concentrar as instituições polonesas em uma organização central, viam esta iniciativa com certa reserva, havendo inclusive descrenças no sucesso de tal empreendimento. Outros, no entanto, avaliavam como sendo o momento mais propício de formação de uma associação ampla, concentrando-se nos benefícios para a colonização polonesa no Brasil. ${ }^{\text {xiv }}$ Conforme Neumann, na vizinha argentina e no Uruguai, após período de discussões, havia sido criada a Federação das Sociedades e Organizações Nacionais Polonesas. Nos Estados Unidos da América, havia a União Católica Romana-Polonesa e a União Nacional que 
reuniam diferentes sociedades e associações menores. Segundo o autor, na França onde existiam em torno de oitocentos mil imigrantes poloneses, não havia quaisquer iniciativas de organização central e apenas as instituições da Alemanha estavam concentradas em uma organização central. ${ }^{\mathrm{xv}}$ Enquanto isso, no Brasil, funcionavam diferentes sociedades e associações, como a Oświata, que agrupava em torno de setenta instituições. A Kultura, por sua vez, era uma das associações com maior número de filiados. $\mathrm{O}$ autor informava ainda, que a Associação dos Professores Poloneses do Brasil desenvolveu-se rapidamente, congregando professores de sociedades em diferentes municípios do Brasil. Em Porto Alegre, a União das Associações Polonesas do Estado Rio Grande do Sul, ligada a Kultura, congregava diferentes sociedades, buscando direcionar ações organizativas nas colônias do estado.

Porém, na avaliação do autor, era fato que nenhuma organização ampla teria suprido as necessidades de unidade da comunidade polonesa no Brasil. ${ }^{\mathrm{xvi}}$ Todas as tentativas eram limitadas à algumas atividades pontuais, e a criação de uma organização ampla deveria ser preparada com prudência. O autor avaliava o estatuto da União Central dos Poloneses como algo não muito claro, em relação à religião, especialmente no campo da educação. Para o autor, a maioria das comunidades polonesas se apoiava nos princípios do catolicismo e não bastava o estatuto de forma genérica afirmar que as crenças pessoais seriam respeitadas. A escola era importante para a Polônia Brasileira, assim como igualmente a Igreja. ${ }^{\text {xvii }}$

$\mathrm{Na}$ edição do dia 29 de março de 1930 do jornal Lud, o artigo principal em primeira página dizia que o dia 23 de março daquele ano foi escrito com letras douradas, como o dia da reconciliação e defesa na polonidade em terras brasileiras. ${ }^{\text {xiii }}$ Apesar de ser um desejo antigo, a União dos Poloneses do Brasil era um fato consumado. Era um despertar para a necessidade de unir os poloneses do Brasil em uma mesma organização, sem supostos anseios ambiciosos, competindo internamente entre si.

Porém, os ditos anseios e as competições internas sobressaíram-se na condução dos processos organizacionais, pelo fato de que, apesar de no discurso incorrer uma certa homogeneização de objetivos, a própria organização Oświata, representada pela Igreja católica, permaneceu na CZP por apenas dois anos, desenvolvendo posteriormente suas atividades de forma autônoma novamente.

Enquanto o periódico Lud dava relevância ao assunto da fundação da CZP, em diferentes edições semanais, o periódico Gazeta Polska w Brazylii pouca atenção deu ao fato da constituição da organização. Em um dos raros artigos sobre o assunto na época, o 
periódico Gazeta Polska w Brazylii dizia que à frente da tarefa de unir os poloneses no Brasil, estavam pessoas competentes incentivadas para trabalharem juntas pelo então Cônsul polonês Kazimierz Downarowicz. ${ }^{x i x}$ Com diferentes delegados representando sociedades de todo o Brasil, os trabalhos foram começados ainda no sábado dia 22 de março, com discursos de lideranças como Szymon Kossobudzki e Konrad Jeziorowski, lideranças étnicas em Curitiba. Cita o referido periódico que no domingo foram discutidos o estatuto da CZP e que, após a terceira leitura, foram adotadas algumas emendas religiosas, sem deter-se sobre quais seriam essas emendas. ${ }^{\mathrm{xx}}$ Informava ainda, que como primeiro presidente da Associação foi eleito Jan Grabski, que, posteriormente em 1938, no período da nacionalização, teria colaborado com os militares brasileiros.

As aspirações das sociedades escolares e agrícolas isoladas, de manterem organizações conjuntas, era uma necessidade no sentido de estabelecer a direção de esforços dispersos, bem como construir relações e contatos entre organizações num escopo de ação mais amplo. Dentre as questões da CZP, consideradas como urgentes, para satisfazer as necessidades da colônia polonesa, estavam também questões como o excesso de produção e a pouca rentabilidade ou, ainda, as formas mais apropriadas de conduzir uma agricultura mais racional, que avançasse o patamar de subsistência das propriedades. $^{\text {xxi }}$

Apesar do pós-guerra em 1920, trazer uma nova perspectiva de união dos poloneses do Brasil em torno do ressurgimento da Polônia no cenário europeu, no campo organizativo étnico, associações como a Kultura, de tendências progressistas e antirreligiosas, e em 1921, a organização da Oświata, justamente de tendência religiosa, focaram seus esforços para estabelecer um programa unilateral de organização das sociedades e demais entidades étnicas polonesas. Visaram agregar em torno de si mesmas o movimento organizacional étnico, buscando difundir um sentido específico de polonidade. Em conjunto com essas iniciativas, foram organizadas justamente em Curitiba outras associações com fins de congregar interesses, tais como União de Juventude, Associação de Educação Física Junak, Associação de Professores e Associação de Agricultores que estavam em certo sentido inseridos nos programas da Oświata e da Kultura. No entanto, ambas as associações não abarcavam um conjunto qualificado de esforços, uma vez que cada organização defendia o seu programa no campo organizacional. Para fins de manifestação sobre as questões organizativas, as associações formavam suas comissões para estabelecer seus pontos de vista sobre questões que importavam para toda a vida organizacional polonesa, sempre partindo de um ponto de 
vista unilateral. Esse processo, muito delimitado pelos programas que seguiam, produzia discussões sobre a necessidade de se estabelecer a unidade organizacional baseada nas questões de importância geral. A questão de ordem do momento era o progresso e a prosperidade dos poloneses no Brasil e o estreitamento de relações com a "pátria" polonesa.

Mesmo o estatuto da União Central dos Poloneses no Brasil previa que o objetivo da instituição era agrupar, numa organização central, todas as sociedades e os grupos poloneses, e pessoas de origem polonesa no Brasil, a fim de desenvolver e elevar o nível da vida cultural, educacional e econômica, trabalhando para a satisfação das necessidades espirituais, como também para a manutenção do estreito contato com o país de origem, no caso a Polônia. ${ }^{x x i i}$

Embora muitas associações nos distintos rincões permanecessem indiferentes às ações empreendidas por essas associações mais amplas, como podemos atestar pela análise do censo individualizado ${ }^{x \text { xii }}$ das escolas étnicas polonesas, organizado pelo consulado polonês e pela própria CZP. No entanto, a organização de uma associação central para congregar todas as instituições étnicas do país era uma necessidade, enquanto organização que disporia sobre a relação entre os contingentes étnicos poloneses do Brasil e as instâncias governamentais brasileiras e polonesas.

A organização da CZP tinha como principal objetivo mobilizar a imigração polonesa. Mesmo o governo polonês entendia que a instituição atuaria em favor dos interesses econômicos da Polônia. O Brasil de proporções territoriais importantes, possuía muitos recursos naturais, sendo considerada a terra do futuro, inclusive como mercado para produtos da indústria polonesa, porque havia o entendimento de que a indústria nacional brasileira não supria a demanda interna de produtos industrializados. ${ }^{\text {xxiv }}$

Os esforços de constituir uma organização central visavam a elevar o nível das escolas elementares; organizar escolas secundárias; formar cooperativas agrícolas e industriais e profissionalização nas comunidades, além de outras iniciativas que visassem a melhoria à existência do grupo étnico polonês. A gama de atividades consideradas urgentes para a imigração polonesa fundamentava a necessidade de organização de uma entidade que representaria legalmente a Polônia brasileira junto às autoridades locais, como também a manutenção das relações com entidades imigratórias na Polônia e com a União dos Poloneses no Exterior, entidade que buscava manter laços com imigrantes poloneses em todos os destinos emigratórios do mundo. 


\section{A Nacionalização e o fechamento de instituições étnicas polonesas}

Até 1938 diferentes instituições étnicas polonesas com diferentes intuitos ou objetivos atuavam no Brasil. Pode-se considerar que havia uma intensa vida cultural étnica caracterizada pela organização de sociedades e associações dos imigrantes poloneses, em núcleos ou comunidades. Com uma pretensa atuação unificada estava a $\mathrm{CZP}$, como portavoz das relações entre as comunidades étnicas e instâncias ligadas ao Ministério das Relações Exteriores polonês - MSZ. Além desta instituição, funcionavam outras associações amplas nacionais como a Associação dos Professores Poloneses do Brasil; a Liga Marítima e Colonial - LMK; o círculo de juventude e desportos, JUNAK, que tinha sociedades filiadas nos três estados do Sul do Brasil; como também a própria Oświata, que funcionou até 1942, apesar da troca de nome para Federação Católica, como associação autônoma e atuante na organização escolar e religiosa dos imigrantes poloneses. Existiam ainda associações regionais como a Federação das Sociedades Polonesas do Rio Grande do Sul, ligada a CZP. A intensa vida cultural étnica da imigração polonesa no Brasil até esse período, pode ser mensurada também pelos diferentes periódicos que circulavam nos núcleos imigrantistas poloneses, tendo como principais protagonistas o Lud e o Gazeta Polska w Brazylii editados por um período maior, além de outras publicações de diferentes órgãos e associações étnicas com diferentes tempos de duração.

A Primeira Guerra Mundial trouxe consequências diretas para o enfraquecimento dos velhos sistemas políticos baseados no positivismo, fazendo com que fossem gestadas novas tendências ideológicas. Os anos 20 do século XX, foram, de certa forma, um período de estagnação econômica, com a industrialização progredindo muito lentamente (KRASICKI, 1983). A dependência econômica do café e a depressão de 1929 acenderam o desejo por mudanças sociais drásticas nos anos 30. Apesar de Vargas surgir como uma nova via de mudanças de emergências sociais e econômicas, como em todas as fases populistas, em face das expectativas de camadas da sociedade, como ocorre atualmente, sua ação política apoiada pelo Exército é mais enfática com o golpe de 1937, quando anuncia uma nova Constituição Federal como um símbolo de unificação da nação brasileira, acima de interesses individuais. No entanto, seu papel acima das ideologias de esquerda baseou-se em ações autoritárias e chauvinistas.

A própria Constituição de 10 de novembro de 1937, que implantou o Estado Novo e a mudança do regime político, trouxe em seu bojo inspirações autoritárias com cunho 
conservador de regimes semifascistas e fascistas europeus, como o de Piłsudski e de Mussolini. A Constituição de 1937, conhecida pelo apodo de "polaca", por ser inspirada na constituição polonesa de $1935,{ }^{\mathrm{xxv}}$ previa poderes ilimitados ao Executivo e total subordinação dos demais poderes.

A tarefa nacionalista era composta também pela luta contra os regionalismos, no sentido de moldar uma nação, dita moderna, defrontando com os antagonismos regionais. Vargas necessitava uma ação direta, a fim de manter uma unidade diretiva nos estados. Essa tendência fez com que nomeasse interventores para fins de mobilizar suas ideologias e unificar o discurso contra os antagonismos regionais e controlar a atividade das autoridades nos estados, bem como dos chamados grupos alienígenas que atuavam no país.

Segundo Kula (1978), em 1930 foi criado o Ministério da Educação, cuja tarefa era transformar o sistema de ensino, unificar e, ao mesmo tempo, eliminar os antagonismos estaduais e regionais, com ênfase no ensino da História e geografia do Brasil e à modernização do Ensino Superior. Porém, a característica mais marcante da Era Vargas foi a dissolução e repressão de todos os antagonismos políticos, bem como dos grupos que os representavam, certo de que a grande força de manifestação e ação estavam voltadas para as lideranças regionais como entraves. Os grupos estrangeiros e a ideologia comunista se mostravam atuantes no horizonte político nacional.

As leis nacionalizadoras não foram exclusivas da imposição do Estado Novo. Segundo Krasicki (1983), já no início dos anos 30 Vargas havia claramente dirigido regulamentos contra estrangeiros e imigrantes, no sentido de normatizar o mercado de trabalho. Stanis Hesel em 1934, enquanto representante da União dos Poloneses do Exterior, que atuava junto à $\mathrm{CZP}$, dizia que a pressão nacionalista não afetava somente os poloneses, mas também outros grupos bem-organizados, e que estas tendências estavam se transformando em pensamento chauvinista, apoiadas por muitos intelectuais brasileiros. ${ }^{\text {xxvi }}$ No ano de 1935, durante a Intentona Comunista, em uma política particular antiestrangeira, estabeleceram-se cotas anuais para diferentes grupos de imigrantes que viriam para o Brasil, proibindo a concentração de imigrantes e promovendo a organização de colonizações mistas de diferentes grupos. Mesmo a "Lei Monstro", como ficou conhecida a Lei de Segurança Nacional, continha uma série de penalidades contra os direitos individuais sobre quem atentasse contra a ordem social estabelecida, bem como contra a unidade da Federação.

Um importante fator foi a criação do Conselho de Segurança Nacional por aquela 
Constituição, composto basicamente por generais do Estado Maior do Exército, que representou a integração maciça das forças armadas nos rumos da política brasileira e na condução e sustentação do regime golpista de Vargas. ${ }^{\text {xvii }}$

Os temores são justificados pelas diferentes interpretações sobre o próprio contingente de estrangeiros que habitavam as regiões isoladas do Brasil e seus modos de existência. Anteriormente considerados como necessários para a consolidação territorial e para o desenvolvimento de regiões despovoadas, agora transformam-se em ameaça à integração nacional e ao projeto de construção do sentido de brasilidade desejada pelas classes conservadoras do país.

Com a decretação do Estado Novo, o horizonte das atividades das associações amplas de imigrantes passa ser considerada como atividades desnacionalizadoras ou desagregadoras da unidade brasileira. Conforme ofício em dezembro de 1937, o General Meira de Vasconcellos realizou ampla reunião em Curitiba, com todos os representantes de associações e outras instituições de imigrantes. A comunicação mais emblemática era a de que precisava-se nacionalizar imediatamente a educação. Esse processo estaria sendo voltado ao ensino pré-escolar, às escolas primárias e às escolas secundárias, assim como a todas as instituições culturais e desportivas, ditas estrangeiras. Todos aqueles que não cumprissem as diretrizes e os ordenamentos das autoridades deveriam preparar antecipadamente o passaporte e deixar o Brasil. ${ }^{\text {xxviii }}$

Nos primeiros meses de 1938, começam a atuação das forças armadas brasileiras no sentido de cumprir os propósitos nacionalizadores da política do Estado Novo. Uma das primeiras instituições étnicas polonesas mais amplas a ser fechada compulsoriamente foi a Associação dos Professores Poloneses do Brasil no dia 14 de março de 1938. Em publicação do Jornal "O Dia", xxix utilizando-se de um tom xenofóbico, o General Meira de Vasconcellos, então comandante da $5^{\text {a }}$ Região Militar, ${ }^{x x x}$ classifica o fechamento da Associação dos Professores Poloneses do Brasil, como uma iniciativa patriótica e acertada pelas autoridades policiais civis. Embora o General Meira de Vasconcellos atribuísse o fechamento da Associação a autoridades civis, o enfoque do desenvolvimento das ações compulsórias era comandada pelos militares.

Włodzimierz Radomski, então presidente da Associação dos Professores Poloneses do Brasil, encaminha uma representação por escrito ao então General-Comandante da $5^{\text {a }}$ Região Militar, para que as atividades da instituição fossem retomadas, alegando que a Instituição, existia exclusivamente para fins educacionais. Afirmava no documento que as 
finalidades da Associação eram legítimas e que, segundo seus estatutos, a associação tinha por objetivo congregar os professores particulares, garantindo-os materialmente, melhorando sua situação financeira e moral. Dentre os outros objetivos, estavam a manutenção de cursos de aperfeiçoamento e a elaboração de programas de ensino para as escolas étnicas polonesas. Citando os estatutos, afirmava que a Associação não tinha nenhuma intenção de contrariar os interesses do Brasil, sendo, nesse sentido, um auxílio aos poderes públicos na gestão das escolas particulares, se estas observassem as leis em vigor.

O presidente Radomski, na representação, faz um histórico das razões de existência das escolas étnicas polonesas no Brasil, na promoção de ensino aos desassistidos pelo ensino público brasileiro. Lembrava dos esforços dos imigrantes poloneses na condução e no desbravamento das colônias, alcançados pelo esforço próprio. Ademais satisfeitas as necessidades de subsistência ou materiais, esses imigrantes buscaram organizar instituições que atendessem aos anseios morais e espirituais. Como havia falta de escolas públicas, os colonos fundaram associações para minorar o problema, construindo prédios e organizando o ensino. O esforço teve êxito, indicando, inclusive, que o número de analfabetos nas colônias polonesas era mínimo. Informava que os alunos das escolas particulares recebiam instrução em Língua Portuguesa, em conformidade com os programas oficiais e rudimentos da Língua Polonesa, em horários extraclasse.

A Associação teria surgido pela necessidade de organização do ensino, sendo, por este motivo, de utilidade pública, colaborando com o Estado brasileiro na campanha contra o analfabetismo. Segundo Włodzimierz Radomski, antes da fundação da associação, os professores particulares não tinham garantias salariais ou melhores condições de vida. Quando a associação completou 10 anos de existência, a maioria dos professores possuía diploma de habilitação ao magistério primário e grande parte das escolas estavam registradas nos departamentos competentes, de acordo com as leis que regiam o ensino particular nos diferentes estados do Brasil. O representante usava as estatísticas oficiais para justificar a ação da associação, afirmando que somente $26 \%$ das crianças em idade escolar podiam frequentar normalmente uma escola no Brasil. A associação contribuiria com a oferta de ensino escolar nas colônias.

Porém, apesar dos apelos e protestos, a resposta do General Meira de Vasconcellos foi uma acusação contundente de que as escolas ditas estrangeiras proporcionavam apenas uma educação não nacional, voltada para uma cultura que não era a brasileira. 
Seríamos um povo sem fibra e sem virilidade, se deixássemos que essa ação se processasse no decorrer da segunda infância e da adolescência, a ponto de termos, na maturidade, brasileiros nominais, vivendo em sua própria pátria como perfeitos estrangeiros. (GENERAL MEIRA DE VASCONCELLOS). ${ }^{\text {xxi }}$

O intuito dos dirigentes da Associação era de que o General Meira de Vasconcellos suspendesse o fechamento da entidade, como forma de justiça às finalidades da Associação.

O fechamento de associações mais amplas não ficou restrita à Associação dos Professores Poloneses do Brasil. Em correspondência consular, Gieburowski ${ }^{\text {xxxii }}$ informa que, no dia 15 de março, as atividades do escritório da Liga Marítima e Colonial também haviam sido suspensas em Curitiba. Na oportunidade o cônsul afirmava que era esperado que essas ações também seriam estendidas para outras organizações étnicas polonesas. ${ }^{\text {xxiii }}$ Um projeto da pretensa reconstrução nacional, começa a ser operado no Brasil, a partir de novas diretrizes que envolvia principalmente a educação étnica e, segundo os difusores da nacionalização, o problema deveria ser encarado do ponto de vista cívico nacional. Conforme este entendimento, escolas, sociedades e associações estrangeiras, disseminavam ideários estranhos ao ambiente nacional, podendo trazer resultados funestos para a nacionalidade e patriotismo brasileiro. ${ }^{\text {xxxiv }}$

Em coluna obrigatória no jornal bissemanário Lud, intitulada de secção de nacionalização, no artigo "Contra a desagregação nacional - pela integridade do Brasil”, o Capitão Emanuel Almeida de Moraes diz:

\begin{abstract}
A remessa para o Brasil de professores públicos poloneses, com denominação de instrutores escolares e até mesmo oficiais do Exército, constitui fatos revoltantes que completa e patenteia a obra criminosa dos inimigos da pátria brasileira. Verdadeiros missionários de estufa, tartufos perigosos, encarregados de crear uma babel de língua e sentimentos de pátrias artificiais; de ensinar a juventude a trair a terra que nasceu, corroendo premeditadamente os mais poderosos vínculos formadores da nossa integridade (EMANUEL ALMEIDA DE MORAES, 18 de junho de 1938). ${ }^{\mathrm{xxx}}$
\end{abstract}

O momento se prestava para um ajuste nos rumos do entendimento da educação nacional, no sentido de promover um processo que fizesse jus aos ideais de nacionalidade propagados pelo regime de Vargas e dos militares. 
Na Polônia, os sentidos apresentados pelo Ministério das Relações Exteriores polonês, era de que, apesar dos protestos e de notas encaminhadas ao governo brasileiro, o curso nacionalista seguia com força, sendo um perigo para as instituições étnicas polonesas no Brasil. O departamento consular polonês aguardaria a resposta a notas enviadas para o governo brasileiro para tomar outras providências sobre o assunto, considerando as ações de fechamento da CZP e da Associação dos Professores das Escolas Polonesas do Brasil, bem como do escritório da LMK, como uma situação perigosa para a imigração polonesa no Brasil. ${ }^{\text {xxxvi }}$

\section{A finalização das atividades da CZP no Brasil}

A ação nacionalizadora progrediu fortemente nos três estados do Sul em 1938 por meio de Leis e Decretos do executivo nacional brasileiro, que eram replicados conforme o entendimento dos interventores estaduais e do comando da $5^{\text {a }}$ Região do Estado Maior do Exército. Esses entendimentos e imposições justificaram a emissão de diferentes documentos secretos pelo consulado geral da Polônia em Curitiba. O Cônsul Gieburowski afirmava que, no dia 14 de março de 1938, as duas principais instituições étnicas polonesas do país foram compulsoriamente fechadas em Curitiba pelo Chefe da Polícia Política. Conforme documento, o Chefe de Polícia convocou os representantes da CZP Centralnego Zwiazku Polaków w Brazylii - União Central dos Poloneses do Brasil e a Zrzeszenia Nauczycieli Szkol Polskich w Brazylii - Associação dos Professores das Escolas Polonesas no Brasil, e exigiu que as atividades destas instituições fossem prontamente suspensas. ${ }^{\text {xxxvii }}$

Havia certa noção de que estes ordenamentos eram momentâneos e que poderiam ser revertidos. Apesar dos esforços empregados na área jurídica por parte da CZP, visando a retroceder da decisão do Chefe da Polícia Política, a proibição do funcionamento dessas instituições jamais foi suspensa. O então Presidente da CZP, Józef Piekarski, enviou um memorial endereçado ao Presidente do Brasil, Getúlio Vargas, com a finalidade de protestar em favor das instituições, o qual foi entregue ao General Meira de Vasconcellos. O memorial dizia que a União Central dos Poloneses no Brasil era uma instituição de caráter privado e apolítico, com finalidades culturais e educacionais. Dizia o documento que a União Central dos Poloneses do Brasil, enquanto representante de centenas de sociedades e associações no Brasil, estava profundamente ofendida com o encerramento 
das suas atividades, e apelaria para um suposto senso de justiça do então Presidente Vargas, para que suspendesse o fechamento da Instituição. O Presidente da CZP ainda enfatizava que a lealdade, diligência e honestidade da relação polono-brasileira eram motivos para manter a confiança em relação aos poloneses. ${ }^{\text {xxxviii }}$ Porém, o General Meira de Vasconcellos não acolheu quaisquer alegações e dizia que, em última análise, o Presidente Vargas considerava corretas as medidas adotadas. O cônsul ainda informava que, no dia 18 de março, havia sido enviado ao escritório da CZP e da Associação de Professores, três policiais que recolheram os arquivos destas instituições e orientava que as correspondências deveriam ser enviadas por meio do consulado. ${ }^{\text {xxix }}$ No dia 22 de março de 1938, o consulado em Curitiba envia documento estritamente secreto para o Ministério das Relações Exteriores polonês, relatando as principais ações empregadas pelas instituições polonesas na luta para que fossem retomadas as atividades outrora fechadas. Informava que da ação do distrito militar no Paraná surtiram efeitos imediatos para o funcionamento das principais instituições étnicas dos imigrantes poloneses no Brasil, dentre elas a CZP. Relatava que uma delegação foi criada com a finalidade de reabrir o curso normal dessas entidades, porém, não teria sido recebida pelas autoridades militares paranaenses. O documento informava que a frase do general Meira de Vasconcellos era a seguinte: "Conheço nos mínimos detalhes as instituições fechadas e não preciso de qualquer explicação", ${ }^{x 1}$ dizia o general, apesar dos protestos dos representantes da comunidade étnica polonesa.

Um novo documento foi entregue ao General Meira de Vasconcellos pelo então presidente da CZP, Józef Piekarski e pelo Secretário Aleksander Ziółek. O objetivo era novamente protestar contra o fechamento da Instituição e tentar uma reconsideração do ordenamento. Os gestores alegavam diferentes motivos que contrariavam as ordens de fechamento. A principal alegação era de que ainda não eram conhecidos os motivos da resolução de fechamento. Argumentavam que, desde 1931, a organização cumpria suas obrigações estatutárias de forma legal. Sua finalidade era simplesmente ajudar na organização cultural dos poloneses, bem como no auxílio material às necessidades existentes nas colônias.

Para os autores da representação, o imigrante polonês havia chegado ao Brasil por meio de convites e, ao longo de muitos anos, no lugar de florestas, criou colônias agrícolas que contribuíam para a riqueza do país, sendo legítima a composição de um círculo de amizade entre o Brasil e a Polônia, nas esferas econômicas e sociais. Citam ainda ações no 
campo de organização agrícola e agropecuária, quando da inauguração de um criadouro de gado trazido da Polônia para a colônia Afonso Penna, no Paraná e a fabricação de produtos de linho na Colônia Cruz Machado, também no Paraná.

\begin{abstract}
Há provas eloquentes de que, desde a época em que o imigrante (polonês) veio para o Brasil, aqui, sob o Cruzeiro do Sul, tentou organizar sua casa e sua família de maneira exemplar e nunca deixou de pensar no bem do país. Além disso, o elemento polonês-brasileiro não diminuiu sua origem. Seguindo os passos de seus ancestrais, exercendo direitos, pagando impostos, proporcionou ao país bons cidadãos e soldados. Não tendo educação suficiente, por falta de escolas públicas, os poloneses tentaram estabelecer escolas privadas, desde o início, cooperando com as autoridades na luta contra o analfabetismo. Assim, um grande número de fábricas, círculos agrícolas, muitas instituições culturais e educacionais, bem como sociedades mistas, foram organizadas, o que é uma prova irrefutável da altivez do elemento polonês. No Brasil, tudo isso foi feito para exaltar esse Brasil como a pátria adotiva desses imigrantes, bem como o berço de seus filhos. ${ }^{x l i}$
\end{abstract}

A este tempo, a crença era de que seria possível reverter os atos nacionalizadores das organizações centrais dos imigrantes poloneses, principalmente advindo das lideranças dessas instituições, tais como a CZP, a Associação dos Professores Poloneses do Brasil.

No entanto, o nacionalismo que estava sendo implantado foi gestado no entendimento de uma política de Estado do governo Vargas, ao qual não havia previsão de retrocessos ou concessões. Não somente a comunidade polonesa sentia os efeitos do processo nacionalizador. Era uma política de imposição de um Estado Patriótico Brasileiro, que atingia todos os grupos de imigrantes. ${ }^{\text {xlii }}$

Conforme o consulado polonês, a resposta considerada "brutal" do General Meira de Vasconcellos aos ofícios e às representações das principais instituições polonesas recebia aplausos da imprensa chauvinista brasileira. Artigos como o intitulado "Lição de Brasilidade" de Plácido da Silva, então Diretor do Jornal Gazeta do Povo, da cidade de Curitiba, enfatizavam que os brasileiros apoiavam o General Meira de Vasconcellos, o que era de suma importância para a representatividade da nação brasileira perante o mundo. ${ }^{\text {xliii }}$

Informava o cônsul polonês em Curitiba que a manifestação do General Meira de Vasconcellos celebrava o entusiasmo da imprensa brasileira em noticiar e promover a Campanha de nacionalização, inclusive com agradecimentos públicos veiculados pelo Jornal Gazeta do Povo, em relação ao fechamento da Associação dos Professores Poloneses do Brasil e da CZP. ${ }^{\text {xliv }}$ Outros artigos em diferentes jornais, como "Ato glorioso e patriótico do General Meira de Vasconcellos"xlv do jornal $O$ Dia de Curitiba e "O direito 
da terra acima do direito de sangue", xlvi do jornal Diário da Tarde inferiam o momento contundente de repressão às organizações étnicas no Brasil.

\begin{abstract}
Voltamos ao assunto, por ser este, como é evidente, de suprema importância. E pelo fato de reclamar, não medidas transitórias e paliativas, mas radicais. Somos e sempre fomos dum liberalismo amplo, senão exagerado. E por isso, quem criou a situação desvendada no decurso da grande guerra e prolongada até a atualidade, não fomos nós os brasileiros, mas sim, os imigrantes. Muitos destes, diremos mesmo, umas pequenas partes destes, abusaram de nossa hospitalidade, premeditavam o enquistamento de nucleação étnica na estrutura nacional, para facilitação de planos imperialísticos (Diário da tarde, 24 de março de 1938). ${ }^{\text {xlvii }}$
\end{abstract}

A própria imprensa, sobre a questão da nacionalização, pressupunha uma aceitação irrestrita por parte dos grupos estrangeiros e que estes, de forma imediata e sem hesitação, renunciariam à sua nacionalidade, língua e costumes, e quem não concordasse, deveria deixar o Brasil. Esta questão de ordem mobilizava a ação da Campanha de Nacionalização em seus ditames repressivos, inclusive com conflitos e perseguições civis a tudo o que fosse considera estrangeiro. ${ }^{\text {xlviii }}$

A tônica da imprensa, a que o cônsul polonês chamava de "cada vez mais hostil aos estrangeiros", era inspirada pelas forças armadas, com consequências nas ações das autoridades civis, que consentiam novos movimentos em favor da Campanha de nacionalização. ${ }^{\text {xlix }}$ As publicações da imprensa, consideradas então agressivas aos estrangeiros, multiplicavam-se e segundo o cônsul era impossível dar atenção a todas. A situação, não atingia somente o grupo étnico polonês, o que desencadeava também reclamações abertas do Reich Alemão, impulsionando manifestações contra a chamada perseguição de minorias étnicas reclamadas em correspondências publicadas pela imprensa brasileira. ${ }^{1}$

O cônsul em Curitiba reclamava de ameaças e quais seriam as causas da ação repressiva contra as organizações polonesas. As manifestações da imprensa brasileira contra os estrangeiros, no Sul do Brasil, estariam tornando-se violentas, podendo inclusive suscitar ações excessivas de confronto civis. Alguns fatores, segundo o cônsul, indicavam que o serviço de inteligência brasileiro estava funcionando de forma mais efetiva do que em anos anteriores, inclusive com a participação de agentes russos do Czar, deposto pela Revolução Soviética. O cônsul recomendava cautela para ativistas e lideranças polonesas que desenvolviam suas atividades no Brasil. Do propósito do cuidado com a ação anti- 
polonesa, as recomendações incluíam os instrutores culturais pagos pelo governo polonês. ${ }^{\text {li }}$

Em respostas às ações nacionalistas no Brasil, conforme despacho urgente, de 7 de abril de 1938, o governo polonês buscava amenizar as consequências por meio do Ministério das Relações Exteriores no sentido de defender supostos direitos dos imigrantes poloneses. ${ }^{\text {lii }}$

Porém, as ações de repressão contra as organizações estrangeiras permaneciam. Em telegrama enviado para o Ministério das Relações Exteriores da Polônia, o Ministro Plenipotenciário, Tadeusz Skowroński, enquanto enviado extraordinário da República da Polônia, para chefiar a legação polonesa no Rio de Janeiro, relatava que dois funcionários do consulado foram interrogados pelas autoridades militares, ficando detidos por várias horas. Dizia o ministro-chefe da legação polonesa que protestou no Ministério das Relações Exteriores brasileiro e iria enviar um "pró-memória” de forma independente, após apresentar as credenciais de ministro ao Presidente Vargas. ${ }^{\text {lii }}$

Em carta encaminhada ao Interventor Federal do Paraná, Manuel Ribas, Gieburowski pede providências sobre o interrogatório dos dois funcionários consulares que ficaram até meia noite do dia 30 de março de 1938, detidos sob a guarda de dois oficiais do Exército, após terem sido interrogados pelo então Delegado de Polícia Mario Queiroz e pelos próprios oficiais militares. ${ }^{\text {liv }}$

Neste período a acentuada repressão, primeiro com o fechamento da CZP e da Associação dos Professores Poloneses do Brasil e posteriormente do escritório da Liga Marítima e Colonial em Curitiba, os militares se preocupavam em compreender, por meio de diligências, a ação de ativistas e instrutores que desenvolviam ações nas instituições étnicas polonesas no Brasil. O Vice-Cônsul Lepecki, em correspondência enviada ao MSZ na Polônia, também informava sobre a ação das autoridades brasileiras, que estaria convocando para diligências instrutores culturais e de ensino que atuavam nas entidades e associações étnicas polonesas, no Brasil. Segundo o documento, foram convocados pelo Delegado de Polícia Mario Queiroz, os instrutores Roman Gajda, Eugeniusz Gruda, Konrad Sadowski, K. Jeziorowski, Włodzimierz Radoński, Eng. J. Skarbek Kruszewski e a Diretora Feminina Bursa CZP, em Curitiba, Ewa Jeżewska, além dos mencionados funcionários consulares Stefan Jankowski e Władysław Wójcik. Alguns instrutores não estavam em Curitiba e foram procurados, como é o caso do Instrutor Michał Sekuła, que atuava mais especificamente no Rio Grande do Sul. ${ }^{\text {v }}$ 
Devido à contundência das convocações, o Vice-Cônsul Lepecki interveio ao ViceGovernador Omar Motta. Segundo documento enviado ao MSZ, o vice interventor declarou, com um pedido de discricionariedade, que as autoridades civis tinham problemas com oficiais do Exército e que estes interferiam na administração e dificultavam o curso normal do processo civil político. Reconhecia a legitimidade das reivindicações do consulado polonês, porém, havia um clima de impotência, no sentido de que nada poderia ser realizado contra a vontade dos militares. ${ }^{\text {lvi }}$

Segundo Lepecki, o interrogatório dos instrutores e funcionários do consulado apesar de ser agendado para às 13 horas, do dia 30 de março de 1938, pelo Delegado de Polícia Mario Queiroz, foram formalmente interrogados por dois oficiais do Exército, sendo o principal deles, o Capitão do Exército Adanto Mello, a quem vice-cônsul chamava de notório chauvinista local. O comitê de investigação conseguiu ouvir apenas três instrutores: R. Gajda, K. Sadowski e Eugeniusz Gruda. Outros instrutores e funcionários consulares, após uma espera de seis horas, foram autorizados a voltar para casa, observando que seriam notificados do prazo para a nova convocação.

Em outro documento consular Lepecki, informa que o interrogatório foi contundente e que os interrogados mantiveram calma e dignidade. Diz ainda que os oficiais brasileiros ficaram surpresos quando os interrogados responderam que eram contratados pelo consulado para atender às instituições étnicas sociais, com grande percentagem de cidadãos poloneses. Segundo Lepecki, este testemunho causou espanto aos militares que esperavam que os instrutores negassem o caráter oficial de suas atividades. No final do interrogatório, os oficiais militares proibiram R. Gajda, K. Sadowski e Eugeniusz Gruda de qualquer atividade nas instituições étnicas, sob a ameaça de prisão.

No caso do interrogatório dos funcionários, havia dois pontos principais a serem analisados no então classificado como incidente pelo Ministério das Relações Exteriores da Polônia: a questão política e a questão legal. A questão política deveria ser excluída do processo, enquanto uma proposição arbitrária do governo brasileiro. A questão legal não estava amparada por uma convenção especial entre a Polônia e o Brasil, no que se refere ao Direito Internacional, excluindo a interferência consular nas relações internas, estando de acordo com os novos rumos político-nacionalistas do Brasil. Ficava ao encargo das próprias instituições buscarem formalmente amparo na legislação brasileira, que estava cada vez mais explícita em desfavor das chamadas sociedades e associações estrangeiras. 
Esses primeiros embates da política nacionalista trouxeram dúvidas, receios e alguns casos até otimismo em relação do futuro das instituições étnicas.

Entretanto, Lepecki diz que a Polônia local reagiria contra a repressão da vida polonesa no Brasil, apesar das autoridades militares buscarem agitar a opinião pública contra os poloneses, por meio de artigos publicados na imprensa e com panfletos, distribuídos por jovens brasileiros na frente de igrejas, com apelos para promover o nacionalismo e manter a sociedade brasileira sob tensão chauvinista. Porém, a Campanha de Nacionalização se expandiu com maior intensidade para o Sul do Brasil. Inclusive autoridades em Santa Catarina suspenderam uma convenção regional da CZP na cidade de Mafra - SC, em que 300 colonos se reuniriam nos dias 26 e 27 de março de 1938. Apesar da proibição, cerca de vinte delegados de sociedades reunidos, secretamente, decidiram que todas as sociedades polonesas, registradas como agrícolas, deveriam ter assinatura de um jornal polonês, e que mantivessem em suas sedes as imagens de heróis nacionais poloneses. Reunidos, sem compreender a gravidade da situação, buscariam fazer de tudo para garantir que a colônia não perdesse o espírito polonês e não se dobrassem diante das represálias. .vii

Lepecki informava ainda, previsões pessimistas do consulado também em relação ao novo Interventor Federal do Rio Grande do Sul, o Coronel Cordeiro de Faria. Segundo o vice-cônsul, o secretário da Educação da nacionalização do estado elaborou um projeto para as escolas particulares, incluídas as escolas alemãs, italianas, polonesas e judias.

A brutalidade dos chauvinistas brasileiros, por meio de decretos arbitrários, era celebrada como feitos gloriosos, inclusive mencionando ações parecidas tomadas pela Argentina e que a nacionalização foi uma invenção brasileira. ${ }^{\text {lvii }}$ Lepecki menciona ainda que o fechamento de escolas e sociedades polonesas no Brasil não afetaria o espírito polonês. Ao contrário, havia casos nos quais pessoas completamente assimiladas suplantavam a Língua Portuguesa de suas casas e, em tom otimista, o vice-cônsul afirmava que a fase atual da perseguição contribuíra para o fortalecimento da consciência nacional étnica entre os poloneses no Brasil. ${ }^{\text {lix }}$

Entretanto, podemos inferir alguns sentidos de incerteza de futuro na documentação analisada em relação às instituições étnicas, declamados pelo setor consular polonês. Como observado no desfecho das ações nacionalizadoras, não houve reconsiderações ou quaisquer retornos ao estado de coisas anterior. A eclosão da Segunda Guerra Mundial ditou novas preocupações e reconfigurações das comunidades étnicas e 
mesmo das instâncias consulares. Associações e sociedades afetadas pela nacionalização jamais puderam retomar suas atividades normais. A ação da CZP no Brasil fora sumariamente findada pelas Leis e Decretos da Nacionalização e pela imposição da política brasileira de busca de uma homogeneização cultural.

\section{Considerações finais}

Nos primórdios da imigração polonesa para o Brasil, forjar a própria existência era a questão de ordem de cada indivíduo, de cada família, enquanto preocupação primeira em um país ainda desconhecido. A organização de sociedades e associações amplas era uma necessidade também vislumbrada no sentido de satisfazer as necessidades de educação e organização cultural étnica, bem como no sentido de fortalecer a pretensa nacionalidade polonesa nos núcleos de imigração.

Num primeiro momento, surgiam as primeiras sociedades, embora limitadas à ação de uma intelectualidade local ou intelligentsia, que mobilizavam o sentido comunitário. $\mathrm{Na}$ fundação das primeiras sociedades e associações, não havia um apoio organizado ou institucionalizado. As sociedades eram organizadas com a finalidade de resolução dos problemas locais, pertencentes à ordem do contexto comunitário, como a edificação do prédio escolar ou construção da capela para as prédicas religiosas. Embora houvesse grandes avanços nas tentativas anteriores de organização de associações mais amplas, como foi, de fato, a existência das associações Kultura e Oświata, o desejo de construir uma instituição ampla centralizada, mobilizou diferentes setores da intelectualidade étnica polonesa do Brasil, principalmente, em Curitiba, no Paraná.

A organização da CZP representou um idealismo de união de todas as sociedades e associações culturais polonesas em 1930, apesar da heterogeneidade de pensamentos e compreensões das estruturas objetivas e subjetivas da etnicidade. Era necessário organizar o trabalho no campo cultural e escolar dos imigrantes poloneses. As tarefas da CZP, conforme seus estatutos, prezavam pelas questões agrícolas, culturais e econômicas do elemento polonês, agindo de acordo com a lei e lealdade aos preceitos políticos e institucionais do Estado brasileiro.

Porém, com a nacionalização, publicações de intelectuais brasileiros davam conta de mobilizar representações nos órgãos de imprensa, que daquele momento em diante a 
juventude e as crianças seriam educadas para amar sua terra natal, sem o culto excessivo à terra natal dos ancestrais, num processo de despertar dos sentimentos pátrios pelo Brasil, combatendo a indiferença pelo local onde nasceram. ${ }^{1 x}$ Esse processo de imposição cultural afetou a vida social de todas as instituições étnicas do país, por meio de legislações que colocavam na clandestinidade as supostas ações estrangeiras no país, com restrições e fechamentos compulsórios de sociedade e associações étnicas.

Apesar do avanço da ação nacionalista no Brasil, houve protestos contra ao que o cônsul Gieburowski caracterizava de chauvinismo draconiano. Em diferentes regiões do país, foram emitidos documentos contendo assinaturas, principalmente de municípios do Paraná, com a finalidade de protestar contra a suposta assimilação pela cultura brasileira. Para o cônsul, a adoção por parte da comunidade étnica polonesa da língua e dos costumes brasileiros levaria os agricultores ao nível de analfabetismo dos "caboclos" brasileiros, com degradação cultural e também econômica. "No Paraná os colonos são os principais produtores em cujos ombros repousa a carga de manutenção do estado. Enquanto somente os brasileiros decidem sobre tudo (na política), o imigrante polonês sempre é mantido de fora" ${ }^{1 x i}$ protestava o cônsul.

Os protestos consulares vinham ao encontro da defesa da organização das instituições étnicas, que desenvolviam e promoviam o fortalecimento de uma pretensa nacionalidade polonesa no Brasil. Havia um ideário que a polonidade deveria ser mantida nas comunidades étnicas e promovida diante das autoridades brasileiras. De modo geral, o fechamento de instituições que mantinham suas atividades nas diferentes comunidades étnicas polonesas, nos estados do Brasil, significaria a repressão contra a própria nacionalidade polonesa, ou contra os sentidos preconizados de uma nação polonesa em terras estrangeiras.

As promulgações do Presidente Vargas, considerando o processo nacionalizador, compunham uma luta pela afirmação dos ideais de brasilidade, frente à promoção das ditas ideias patrióticas, o que impunha um novo pensamento sobre os contingentes de imigrantes no Brasil. O fechamento das organizações polonesas exigiu um plano de ações no campo étnico, em detrimento das conquistas organizacionais das comunidades, em todos os setores culturais, sejam educacionais, linguísticos, econômicos, desportivos e etc. A estratificação desse processo na sociedade brasileira compunha o modo repressivo de pensar a cultura do diferente e das diferenças. $\mathrm{O}$ estrangeiro e o diferente deveriam ser combatidos. Esta palavra de ordem mobilizava a imprensa brasileira em diferentes jornais 
no Brasil, com artigos enfáticos na defesa da campanha de nacionalização e exaltação do governo Vargas, bem como dos próprios militares, que executavam as ações no campo social.

A mobilização dos contingentes étnicos até foi requisitada para que houvesse um revés na Campanha de nacionalização. Porém, a forma eficiente como estava sendo conduzida a campanha de nacionalização pelos militares, utilizando-se da propaganda na imprensa; da intimidação por meio de interrogatórios e mesmo da imposição de tensão chauvinista na sociedade brasileira, reclamada pelo consulado polonês, foram meios efetivos de sedimentar os objetivos dos planos nacionalizadores.

O nacionalismo representa, a esta altura, uma questão importante e primordial para a ditadura varguista. Esse apelo reportava a ideologia do Estado Novo. As comunidades imigrantes representavam separatismos. Era necessária a luta no campo ideológico e social contra os quistos estrangeiros, contra colonos europeus e asiáticos conspiradores a serviço de interesses estrangeiros, prejudiciais à nação brasileira.

A questão educacional era o centro dos debates nos contornos almejados pelo fluxo nacionalizador. O fechamento das associações mais amplas da imigração polonesa no Brasil representa, neste sentido, o ponto central de imposição de uma cultura nacional brasileira principalmente no campo do ensino escolar. O fim das atividades da CZP implicou principalmente no desmantelamento das instituições polonesas que buscavam proteger a cultura étnica por intermédio do fortalecimento dos sentidos de polonidade ou mesmo da ligação entre comunidade imigrante com a Polônia.

\section{Referências}

BARTH, Fredrik. Introducción. In BARTH, Fredrik. (org.), Los grupos étnicos y sus fronteras. México: Fondo de Cultura Económica, 1976. pp. 5-69.

BOURDIEU, Pierre. O poder simbólico. Lisboa: Difel; Rio de Janeiro: Bertrand Brasil, 1989.

CHARTIER, Roger. O mundo como representação. Estudos Avançados, São Paulo, v. 5, n. 11, p. 173-191, abril de 1991.

FOUCAULT, Michel. Microfísica do Poder. Rio de Janeiro, Graal, 2000.

GARDOLINSKI, Edmundo. Escolas da Colonização Polonesa no Rio Grande do Sul. Porto Alegre: Escola Superior de Teologia São Lourenço de Brindes: Caxias do Sul, UCS, 1977. 
GELINSKI, Pedro. Et Al. 75 Anos de presença dos Padres Vicentinos. Curitiba: Gráfica Vicentina, 1978.

GŁUCHOWSKI, Kazimierz. Os poloneses no Brasil. Porto Alegre: Rodycz \& Ordakowski, 2005.

KRASICKI, Marek. Sytuacja Polonii brazylijskiej w dobie ustaw nacjonalistycznych prezydenta Getulia Vargasa. Dzieje Polonii w Ameryce Lacińskiej. Wrocław, v.3 n. 5, pp. 411-441, 1983.

KULA, Marcin. Brazylijski żetulizm jako ustrój autorytarny. Dzieje Najnowsze, n. 1, pp. 117-129, 1978.

MALIKOSKI, Adriano. Escolas étnicas polonesas no Rio Grande do Sul. Caxias do Sul: EDUCS, 2018.

MAZUREK, Jerzy. A Polônia e seus emigrados na América Latina (até 1939). Goiânia: Espaço Acadêmico, 2016.

REIS, José Carlos. História e Verdade: proposições. Síntese: Revista de Filosofia. Belo Horizonte, v.27, n. 89, fev. /jun. pp. 1-33, 2000.

SILVA, Fabiana Regina da. Associações Polonesas União das Sociedades Kultura e Oświata (Curitiba - PR): Antagonismos e polonidade (s) na diáspora (1890 1939). Tese de doutorado do Programa de Pós-Graduação em História da Universidade de Federal de Santa Maria. Santa Maria: UFSM, PPGH, 2019. 394 p

VIEIRA, Carlos Eduardo. Intelligentsia e intelectuais sentidos, conceitos e possibilidades para a história intelectual. Revista Brasileira de História da Educação. Londrina: $\mathrm{n}^{\circ} 16$ jan./abr., pp. 63-85, 2008.

IANNI, Otavio. A formação do proletariado rural no Brasil. In: STEDILE (Org.). A questão agrária no Brasil: o debate na esquerda: 1960-1980. São Paulo: Expressão Popular, 2005. p. 127-144.

WACHOWICZ, Ruy Christovam. As Escolas da Colonização Polonesa no Brasil. Curitiba: Ed Champagnat, 2002.

WACHOWICZ, Ruy Christovam. O camponês polonês no Brasil. Curitiba: Fundação Cultural, Casa Romário Martins, 1981.

Submetido em: 09/08/2020

Aprovado em: $24 / 08 / 2020$

Publicado: 23/09/2020

\footnotetext{
i Este trabalho faz parte de pesquisa mais ampla intitulada "Escolas Étnicas Polonesas", publicado como desdobramento das minhas pesquisas de mestrado e doutorado.

${ }^{i i}$ É graduado em Filosofia e Pedagogia. Mestre e Doutor em Educação pela Universidade de Caxias do Sul.

Faz parte do grupo de pesquisas História da Educação, Imigração e Memória - GRUPHEIM (UCS) e "Os
} 
poloneses e seus descendentes no Brasil: um processo contínuo de integração", do Núcleo de Estudos Populacionais da Universidade de São Paulo - NEP (USP).

iii Contexto no sentido de tempo histórico nas suas conjunções sociais, políticas, econômicas e culturais.

iv Sobre a escolarização dos imigrantes poloneses no Rio Grande do Sul, anterior à independência da Polônia, consultar Malikoski (2018).

${ }^{v}$ Livros de Ata e Protocolo da Sociedade Polônia em Porto Alegre, Sociedade de Lageado Valeriano, na região de Erechim, Sociedades de Ijuí e Guarani das Missões. Arquivos NPH - UFRGS - Acervo

Gardolinski; Arquivo da Sociedade Polônia e Museu Municipal de Áurea.

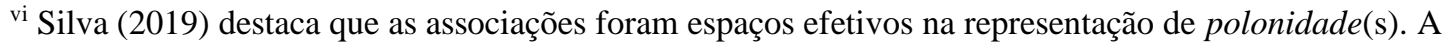
realidade étnica foi configurada de acordo com a mobilização cultural destas entidades na diáspora, a fim de delimitar o pertencimento nacional na coesão do grupo étnico, em torno da Polônia reunificada. As associações representam a união de dois discursos distintos: a Oświata recordando as raízes históricas do catolicismo na Polônia, como o batismo, e a Kultura, retomando o debate político e ideológico da cultura intelectualizada.

vii Estatutos da Sociedade Kultura. In: Wachowicz (2002, p. 54).

viii Sobre o assunto ver Malikoski (2018). Silva (2019) mobilizou importantes fontes para analisar as atividades da Kultura e da Oświata.

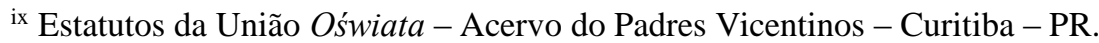

${ }^{\mathrm{x}}$ Lista de livros didáticos utilizados pela União das Sociedades e Escolas Polonesas Oświata. Acervo dos Padres Vicentinos. Curitiba - PR.

${ }^{x i}$ Livro de Atas da Federação Católica. Ata de encerramento das atividades da Federação. APV - Curitiba PR.

xii Sigla em polonês para Centralny Związek Polaków.

xiii Centralny Związek Polaków w Brazylii: faktem dokonanym. In: Lud, Kurytyba, 29 marca 1930 r. p. 01. Arquivo dos Padres Vicentinos - Curitiba - PR.

xiv Neumann, Władysław. Wokoło „Centralnego Związku Polaków w Brazylii”. In: Lud, Kurytybie, 22

Marca 1930 r. Arquivo dos Padres Vicentinos - Curitiba - PR.

${ }^{\mathrm{xv}}$ Idem, s. 4

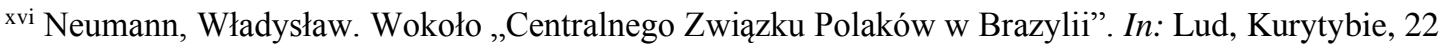

Marca 1930 r. Arquivo dos Padres Vicentinos - Curitiba - PR.

xvii Idem. p. 01.

xviii Centralny Związek Polaków w Brazylii: faktem dokonanym. In: Lud, Kurytyba, 29 marca 1930 r. p. 01. Arquivo dos Padres Vicentinos - Curitiba - PR.

${ }^{\text {xix }}$ Gazeta Polska w Brazylii. Kurytyba, Czwartek dni. 3 kwietnia 1930 r. p. 03.

${ }^{x x} \mathrm{O}$ primeiro conselho da nascente instituição seria formado então pelo jurista Jan Grabski, o Padre Jan Pałka, o instrutor de ensino Michał Sekuła, p. Lachowski, Sr. Aleksander Matuszewski, Sr. Jan Ficiński e Sr. Roman Wachowicz. Gazeta Polska w Brazylii. Kurytyba, Czwartek dni. 3 kwietnia 1930 r. p. 03.

xxi Ver diferentes autores que abordam as questões econômicas do imigrante polonês, como Wachowicz (1970) e Ianni (2005), bem como a extensa documentação consular sobre os colonos poloneses no Brasil. xxii AAN-MSZ n 10794, p. 63.

xxiii Sprawozdanie Szkolne z rok 1937. Os dados apresentados dos relatórios baseiam-se nas cópias que se encontram no Museu de Áurea - RS, complementados pela compilação de Wachowicz (2002).

xxiv Neumann, Władysław. Wokoło „Centralnego Związku Polaków w Brazylii”. In: Lud, Kurytybie, 22 Marca 1930 r. Arquivo dos Padres Vicentinos - Curitiba - PR.

${ }^{x x v}$ Sobre o assunto ver PORTO, Walter Costa. Constituições brasileiras. 3. ed. Brasília: Senado Federal, Subsecretaria de Edições Técnicas, 2012.

xxvi Sprawozdanie Stanisława Hessela do Światowego Związku Polaków w Warszawie z 3 października 1934 roku. AAN 10210.

xxvii Da Segurança Nacional, art. 161. As forças armadas são instituições nacionaes permanentes, organizadas sobre a base da disciplina hierarchica e da fiel obediencia a autoridade do Presidente da República. Art. 162. Todas as questões relativas à segurança nacional serão estudadas pelo Conselho de Segurança Nacional e pelos orgãos especiaes creados para attender á emergencia da mobilização. O Conselho de Segurança Nacional será presidido pelo Presidente da Republica e constituido pelos Ministros de Estado e pelos Chefes de Estado Maior do Exercito e da Marinha. Art. 163. Cabe ao Presidente da Republica a direcção geral da 
guerra, sendo as operações militares da competencia e da responsabilidade dos commandantes chefes, de sua livre escolha. (Idem, p. 89-90).

xxviii Cônsul Gieburowski, Tajne pismo Konsulatu RP w Kurytybie do MSZ, 13 grudnia 1937 roku. AAN, 10382. S. 01.

xxix “Louvável e Patriótica atitude do General Meira de Vasconcellos. Evidencia-se mais uma vez o alto zelo do bravo militar pela nacionalização e grandeza de nossa pátria. Resoluto apoio ao ato do governo estadual fechando a Associação dos Professores Poloneses do Brasil.” O Dia, 22 de março de 1938.

xxx A Nacionalização no Brasil tornou-se um movimento efetivo, quando os militares da $5^{\mathrm{a}}$ Região encaminhavam diferentes dossiês aos setores de segurança institucionais, criados por Vargas, versando sobre a inconveniência da cultura étnica das regiões mais densamente povoadas por imigrantes, nos Estados do Paraná e de Santa Catarina, o que condizia com o espírito ideológico do Estado Novo, associado à exacerbação do nacionalismo dos militares.

xxxi Resposta na imprensa ao pedido de suspensão do fechamento da Associação dos Professores das Escolas Polonesas do Brasil. O Dia, 22 de março de 1938. AAN 10022.

xxxii Cônsul polonês em Curitiba.

xxxiii Cônsul Geral Gieburowski em Curitiba. Tajne 15 marca 1938 r. Poczta Lotnicza Do Ministerstwa Spraw Zagranicznych w Warszawie. AAN 10022 s. 16.

xxxiv “Quem, em boa fé, poderá negar apoio à tão patriótica iniciativa?” - Publicação das organizações católicas. Janeiro de 1938. AAN 10022 s. 14 e 25.

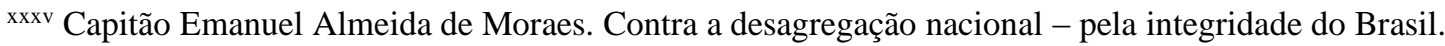
Secção de Nacionalização. In: Lud, Kurytybie, 21 czerwca 1938 r. Acervo dos Padres Vicentinos - Curitiba $-\mathrm{PR}$.

${ }^{\text {xxxi }}$ B. Pilne. Dyrektor Departamentu Konsularnego, do Pana Wicedyrektora Dep. Politycznego. Warszawa, dnia 28 marca 1938 r. AAN 10022 s. 28.

xxxvii Cônsul-geral Gieburowski em Curitiba. Tajne. Poczta Lotnicza Do Ministerstwa Spraw Zagranicznych w Warszawie 15 marca 1938. AAN 10022 s. 16.

xxxviii Josef Piekarski. Do Jego Ekscelencji Pana Prezydenta Getulia Dorneles Vargasa w Rio de Janeiro. (Pró-Memória entregue ao Gen. Meira de Vasconcellos, endereçado ao então Presidente Vargas.) AAN 10022, s. 34.

xxxix Akcji nacjonalizacyjnej. Ścisłe Tajne. Do Ministerstwa Spraw Zagraniczny. Dnia 22 marca 1938 r. AAN 10022 s. 37.

${ }^{x 1}$ Akcji nacjonalizacyjnej. Ścisłe Tajne, Do Ministerstwa Spraw Zagraniczny. Dnia 22 marca 1938 r. AAN 10022 s. 37.

${ }^{x l i}$ Representação do Presidente do CZP, Josef Piekarski ao General Meira de Vasconcellos, comandante da $5^{\circ}$ Região do exército. Jw. Pan. General Dowódca V-Okręgu Wisk w Kurytybie. AAN 10022, s 32.

xlii A rádio de Berlim transmitiu no último dia 21, especialmente para a América do Sul, uma mensagem da imprensa alemã do Reich, protestando contra a perseguição da minoria alemã no Brasil. A comunidade polonesa aqui está simplesmente com anseios de vozes semelhantes da Polônia em relação aos poloneses do Brasil. Akcji nacjonalizacyjnej. Ścisłe Tajne do Ministerstwa Spraw Zagraniczny. Dnia 22 marca 1938 r. AAN 10022 s. 39.

xliii Plácido da Silva, Lição de Brasilidade. Gazeta do Povo, 23/3/1938. AAN 10022, s. 46.

xliv Correspondência de agradecimento do General Meira de Vasconcellos à Plácido da Silva Editor do jornal Gazeta do Povo. AAN 10022 s. 47.

xlv $O$ Dia, 23 de maio de 1938. AAN 10022, s. 31.

xlvi Diário da Tarde, 24 de março de 1938. Hemeroteca Digital da Biblioteca Nacional. Disponível em: http//memoria.bn.br/DocReader/800074/51782. Acesso em maio: 2019.

xlvii Diário da Tarde, 24 de março de 1938. Hemeroteca Digital da Biblioteca Nacional. Disponível em: http//memoria.bn.br/DocReader/800074/51782. Acesso em: maio 2019.

xlviii Ver A Campanha de nacionalização. Diário da Tarde, 25 de março de 1938. Hemeroteca digital da Biblioteca Nacional. Disponível em: http://memoria.bn.br/DocReader/800074/51797. Acesso em: maio 2019.

${ }^{\text {xlix }}$ W sprawie Zrzeszenia Naucz. i reak szuu. W prasie Brazylii., pocztą lotniczą, do Ministerstwa Spraw Zagranicznych w Warszawa. AAN 10022 s. 43.

${ }^{1}$ Idem.

li Idem. 
lii Pismo pilne do Pana naczelnika MSZ. Warszawa, dnia 7 kwietnia, 1938 r. AAN 10022 s. 55.

liii Telegram szyfrowy przychodzący. P. Skowroński do ministerstwa Spraw Zagranicznych w Warszawie. Rio de Janeiro, dn. 7 kwiecień 1938 r. AAN 10022 s. 59.

liv Pisma od Josefa Gieburowskiego, Konsul Generalny R. P. do Jego Interwentora Federalnego Manuela Ribasa. Kurtybie 30 marca 1938 r. AAN 10022 s. 61.

lv Wicekonsul Bohdan Lepecki do Ministerstwa Spraw Zagranicznych. Curitiba 5 kwiecień 1938 r. AAN 10022 s. 87.

lvi Ibidem, p. 2.

lvii Akcja Nacjonalny. i przesz. Inst. Scylle Tajne. Wicekonsul Bohdan Lepecki do Ministerstwa Spraw Zagranicznych Warszawa. Curitiba 5 kwiecień 1938 r. AAN 10022 s. 87.

lviii Idem.

lix Ibidem, p. 3.

${ }^{1 x}$ Komentując: O Luzeiro - Styczeń - 1938. Organ Stowarzyszeń Katolickich w Kurytybie. AAN 10020 s. 24.

${ }^{1 x i}$ Idem. 